\title{
Efficacy of different additives in ensiling faba bean and field pea based whole crop silages
}

\author{
Arja Seppälä ${ }^{1,2}$, Marketta Rinne $^{1}$ and Arto Huuskonen ${ }^{3}$ \\ ${ }^{1}$ Natural Resources Institute Finland (Luke), Tietotie 2 C, Fl-31600 Jokioinen, Finland \\ ${ }^{2}$ Current address: Eastman, Typpitie 1, FI-90620 Oulu, Finland \\ ${ }^{3}$ Natural Resources Institute Finland (Luke), Halolantie 31A, FI-71750 Maaninka, Finland \\ e-mail: arjaseppala@eastman.com
}

\begin{abstract}
Mixed stands of faba bean + wheat (FBW; faba bean 0.84), and pea + wheat (PW; field pea 0.89 on dry matter [DM] basis) were harvested in Siikajoki, Finland. The crops were ensiled in triplicate in laboratory silos using four additive treatments: control without additive, two commercial lactic acid bacteria stains (LAB) and ACID (formic and propionic acids). Ensiling time was 105 days. The crops contained 173 and $181 \mathrm{~g} \mathrm{DM} \mathrm{kg}^{-1}$ and the water soluble carbohydrate (WSC) concentration was 156 and $176 \mathrm{~g} \mathrm{~kg}^{-1}$ DM in FBW and PW, respectively. ACID restricted silage fermentation in FBW (WSC 146; fermentation products $43 \mathrm{~g} \mathrm{~kg}^{-1} \mathrm{DM}$ ). The other silages had high concentration of fermentation products (180-204) and low WSC concentration ( $\left.<22 \mathrm{~g} \mathrm{~kg}^{-1} \mathrm{DM}\right)$. The volatile fatty acid concentration was below $30 \mathrm{~g} \mathrm{~kg}^{-1} \mathrm{DM}$ in all treatments. PW-ACID treatment resulted in higher ethanol concentration and better aerobic stability (>235 hours) compared to control or LAB silages. When ensiling wet legume whole crops effluent losses, extensive fermentation and poor aerobic stability may cause problems.
\end{abstract}

Key words: aerobic stability, fermentation, lactic acid bacteria, Pisum sativum, total mixed ration, Vicia faba

\section{Introduction}

Mixtures of small grain cereals and grain legumes harvested as whole crop silage can give high yield by one harvest also in northern areas. Their agronomic benefits include possibility to use slurry or manure in spring time, nitrogen fixation of legume species and harvest time different from grasses. They may also be used as a cover crop to establish new grass swards.

Phelan et al. (2015) stated that the primary agronomic benefits of legumes are their contribution to the nitrogen economy of agricultural land due to their association with nitrogen fixing bacteria and their ability to increase herbage production, herbage feed value and ultimately ruminant production of meat and milk, particularly in areas of low fertilizer nitrogen input. In Nordic countries faba bean (Vicia faba), field pea (Pisum sativum), common vetch (Vicia sativa) and hairy vetch (Vicia villosa) are commonly used annual forage legumes (Huuskonen et al. 2016).

Grass silage is the major forage fed to cattle in Nordic countries. Grass silage can be partially replaced by whole crop legume-cereal silage without significant changes in animal performance (Lamminen et al. 2015, Huuskonen et al. 2016). Thus, inclusion of grain legume-cereal mixtures into crop rotation and forage production should be justified based on their agronomic benefits (Huuskonen et al. 2016).

Increasing proportion of legumes in the mixture is likely to challenge the ensiling process of the whole crops due to higher buffering capacity and lower dry matter (DM) content of grain legumes compared to cereals (Pursiainen and Tuori 2008). This may lead into poor fermentation quality of the silage (e.g. Borreani et al. 2009). Additional risks related to the harvest of whole crop silage include seed shedding, contamination with soil or dead plant material and high air humidity in the autumn challenging prewilting.

Good management practices are the basis for successful ensiling (Kung 2009). Silage additives can be used to decrease losses related to preservation and thus improve nutrient recovery, prolong aerobic stability and, in some cases, improve animal performance (Kung and Muck 1997). Generally, the purpose of silage additives is to inhibit the growth of undesirable micro-organisms, thus preventing spoilage of the feeds and minimizing nutrient and energy losses.

Majority of Finnish dairy farmers use silage additives. Two main types used are biological additives (lactic acid bacteria either with or without enzymes) or formic acid based additives (Seppälä and Nyholm 2019). Biological silage additives are classified to be stimulators of fermentation while formic acid is an inhibitor of fermentation (Kung et al. 2003). 
Formic acid causes immediate drop in the $\mathrm{pH}$ which is inhibiting respiration, clostridia, enterobacteria and proteolysis caused by plant enzymes (Virtanen 1945, McDonald et al. 1991). Further, formic acid has strong bactericidal effect against several harmful bacteria (Strauss and Hayler 2001). In contrast, lactic acid bacteria need to multiply and convert available sugars into lactic acid before pH drop is possible (McDonald et al. 1991, Kung et al. 2003). While the mechanisms are so different, also the effects on silage quality are different (Seppälä et al. 2016). The difference is well documented even in farm conditions (Seppälä and Nyholm 2019).

Silage additives can also be used to improve aerobic stability after silo opening (Kung et al. 2003). Examples of those include Lactobacillus buchneri, that has proven to be able to improve aerobic stability by increasing silage acetic acid concentration (Kung et al. 2003). There is also several chemical compounds, including propionic acid, propionates, sorbates and benzoates which are used to improve aerobic stability. Inclusion of those into formic acid based blend has enabled creating multipurpose product which can both restrict fermentation and improve aerobic stability (Rinne et al. 2016).

Forage legumes have often shown good stability in ensiling trials (Muck and O'Kiely 1992). However, when whole crops are ensiled, straw may increase porosity and thus cause poor stability after silo opening. Pursiainen and Tuori (2008) ensiled wet field bean-wheat whole crop mixtures in different proportions, and detected temperature increase within one-week follow-up period after silo opening.

Although generally the differences between different types of silage additives are well known, more detailed information is needed when comparing additives on the market. Is there any difference between different biological additives? Or how blends of organic acids effect on silage quality? Is the recommended application level high enough? Are there going to be issues with poor aerobic stability? Always when new products enter to the market, new information is needed. As well, ensiling different crops means different challenges. Applicability of the existing knowledge needs to be confirmed by trials.

A laboratory scale ensiling experiment was conducted to compare the effects of three silage additives and a control without additive on fermentation quality and aerobic stability of faba bean and field pea based mixtures with wheat harvested as whole crop silage without prewilting. It was hypothesised that the use of additives would improve fermentation quality and prolong aerobic stability of the silages.

\section{Material and methods}

\section{Plant material}

Two legume-cereal mixtures, faba bean (cv. Fuego) + wheat (Triticum aestivum cv. Anniina) (FBW) and field pea (cv. Florida) + wheat (cv. Anniina) (PW), were sown on 4-10 June 2013 at the experimental farm of Natural Resources Institute Finland (Luke) in Siikajoki, Finland $\left(64^{\circ} \mathrm{N}, 25^{\circ} \mathrm{E}\right)$. The sowing rates were $174 \mathrm{~kg}$ faba bean with $75 \mathrm{~kg}$ wheat and $138 \mathrm{~kg}$ pea with $75 \mathrm{~kg}$ wheat ha-1. Legumes were first sown into depth of 6-8 $\mathrm{cm}$ and wheat was sown after that into depth of $2-3 \mathrm{~cm}$ crossing first driving lines. The field area cultivated was about 10 ha for both crops separately without field replications. Prior to sowing the field was fertilized using cattle manure. The FBW field received composted cattle manure at a rate of $14 \mathrm{t} \mathrm{ha}^{-1}$ and the $\mathrm{PW}$ field received $22 \mathrm{t}$ cattle slurry ha-1. The amounts of spread nutrients were 50-27-61 and 37-6-40 kg N-P-K ha-1 for FBW and PW, respectively. Both crops were harvested 12 weeks after sowing (26 August) with direct cut precision chopper (Claas Jaguar 870, CLAAS KGaA mbH, Harsewinkel, Germany) when wheat was at early dough stage of ripening. The legumes were still green, only tiny black spots were visible in the leaves of faba bean, which were otherwise green. Pods of the faba bean were green, lower ones filled and upper ones containing immature seeds. Pods of peas were green, either filled with green seeds or still flat. The development of the crops is described in detail by Kuoppala et al. $(2014 \mathrm{a}, \mathrm{b})$. There was no rain at the time of harvesting. The yield (measured from three $12 \mathrm{~m}^{2}$ areas within each field using Haldrup harvester, Haldrup GmbH, Ilshofe, Germany) of FBW was 6783 and that of PW $6839 \mathrm{~kg} \mathrm{DM} \mathrm{ha}^{-1}$. Botanical composition was determined from the material harvested by the Haldrup. The material for the ensiling trial was harvested at 11:00 (FBW) and at 14:00 (PW) without additive and transported immediately to laboratory for sampling and ensiling. The harvested material was not representatively collected from the 10 ha plots due to practical limitations but represented one side of the area in both cases. 


\section{Ensiling and silo opening}

Equal $35 \mathrm{~kg}$ batches (four batches per crop) of plant material were treated with additives described in Table 1. The additives were applied using bottles with right amounts of additives. The bottles had caps with tiny holes, and additives were sprayed via those holes. The additives were evenly sprayed onto plant material that was laying on plastic sheet. Mixing and spraying was done in intervals to ensure even distribution. There was several people working during additive treatments and silo filling so that all four treatments could be done simultaneously without time delays.

Two different lactic acid bacteria products were used (LAB1 and LAB2) which both contained both homofermentative and heterofermentative lactic acid bacteria strains. The chemical additive was based on formic acid (ACID). Additionally, control silos without additive were prepared. For control treatment no water was added to better reflect the practical situation at farm scale. However, the control treatment was mixed similarly as the other treatments. Dosage levels of LAB1 and LAB2 were based on the instructions in the product labels, while dosage level of ACID was lower $\left(5 \mid \mathrm{t}^{-1}\right)$ than recommended by manufacturer for leguminous species $\left(6 \mid \mathrm{t}^{-1}\right)$.

Table 1. Additive treatments used in the ensling experiment

\begin{tabular}{|c|c|c|}
\hline Treatment & Composition & $\begin{array}{c}\text { Application } \\
\text { level }\end{array}$ \\
\hline Control & Nothing added & \\
\hline $\begin{array}{l}\text { LAB1, Bonsilage Alfa, } \\
\text { (H. Wilhelm Schaumann } \\
\text { GmbH, Pinneberg, } \\
\text { Germany / R \&V Euro- } \\
\text { trading Ltd, Kuopio, } \\
\text { Finland) }\end{array}$ & $\begin{array}{l}\text { 1k2071 Lactobacillus plantarum DSM 21762, 1k2076 Lactobacillus paracasei DSM } \\
\text { 16245, 1k2075 Lactobacillus buchneri DSM 12856, 1k2082 Lactococcus lactis NCIMB } \\
30160\end{array}$ & $\begin{array}{l}2.5 \times 105 \\
\quad \text { CFU g } \\
\text { applied with } \\
\text { water } 4 \text { I t }^{-1}\end{array}$ \\
\hline $\begin{array}{l}\text { LAB2, Sil All } 4 \times 4 \\
\text { (Danstar Ferment A.G., } \\
\text { Switzerland / Kärki-Agri } \\
\text { Ltd, Seinäjoki, Finland) }\end{array}$ & 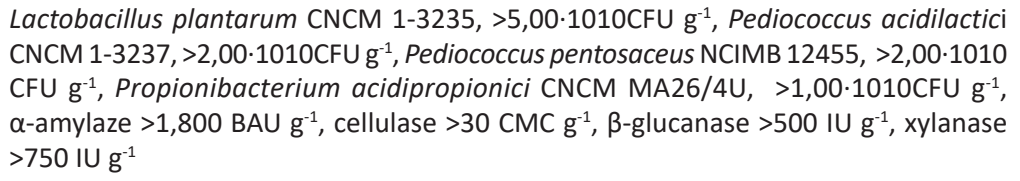 & 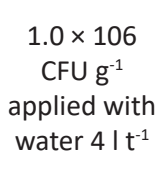 \\
\hline $\begin{array}{l}\text { ACID, AIV }^{\circledR} \text { Ässä } \\
\text { (Kemira Ltd, currently } \\
\text { Eastman, Oulu, Finland) }\end{array}$ & $\begin{array}{l}\text { Formic acid 590, propionic acid 200, ammonium formiate } 40 \text {, potassium sorbate } \\
25 \mathrm{~g} \mathrm{~kg}^{-1}\end{array}$ & $51 t^{-1}$ \\
\hline
\end{tabular}

For each treatment, three replicate silos (cylinder shape, effective volume $12 \mathrm{I}$, diameter $14.2 \mathrm{~cm}, 11.1 \mathrm{~kg}$ FBW or $10.0 \mathrm{~kg}$ PW per silo; respective packing densities 925 and $833 \mathrm{~g} \mathrm{~kg}^{-1}$ respectively for FBW and PW) were filled. Filling was conducted in small batches with intermittent manual compacting. Silo filling was done simultaneously for all additive treatments within the same crop. Silos were sealed immediately after filling by adding a lid, a lead plummet $(8.2 \mathrm{~kg}$ ) and a water bag $(2 \mathrm{~kg})$ on top of each silo. All the silos were closed within 3 hours from harvesting. Silos were stored first in uninsulated storage building and transported to a cool storage room (temperature 2-10 ${ }^{\circ} \mathrm{C}$ ) before outside temperature dropped below zero.

When planning the trial, it was expected that there might be higher proportion of wheat and substantially higher DM concentration. Low DM was unexpected, and therefore preparations were not made for effluent removal. It is notable, that in practise effluent will at least partially stay within silage in many silo types as well as in bales. Effluent was not removed from the silos during ensiling, but a small amount of effluent was lost from some silos due to spill from the top. The uncontrolled effluent runoff prevented measurements of ensiling losses measured as weight change.

Silos were opened after 105 days. The top layer of silage $(5 \mathrm{~cm})$ was removed from each silo and the remaining silage was mixed and sampled for analysing fermentation and microbiological quality and for aerobic stability measurements of silages and total mixed rations (TMR) prepared from each silage.

Each silage was used to prepare TMR batches. A TMR batch included $803 \mathrm{~g}$ of tested silage and $187 \mathrm{~g}$ other feed ingredients on fresh matter basis. The mixture of other feed ingredients included barley, oats and brewer's grain in equal proportions on fresh weight basis $\left(\mathrm{TMR}_{\mathrm{bob}}\right)$ or barley, oats, brewer's grain and straw 320, 320, 320 and $40 \mathrm{~g} \mathrm{~kg}^{-1}$ on fresh weight basis, respectively $\left(\mathrm{TMR}_{\mathrm{bobs}}\right)$. Due to the restricted capacity of aerobic stability measurements, $\mathrm{TMR}_{\text {bob }}$ was prepared only from PW silage treatments control, LAB1 and ACID. 


\begin{abstract}
Analyses
Chemical and microbiological analyses were carried out at the laboratory of Luke in Jokioinen, Finland as described by Seppälä et al. (2016), except for in vitro cellulase solubility which was determined and calculated to Dvalue (digestible organic matter $\mathrm{g} \mathrm{kg}^{-1} \mathrm{DM}$ ) according to Huhtanen et al. (2006) using the equation based on data including legumes. Additionally, enterobacteria were determined on VRBG medium (Violet Red Bile Glucose, Lab $\mathrm{M} \mathrm{088}, 37^{\circ} \mathrm{C} \pm 1{ }^{\circ} \mathrm{C}, 24 \pm 2 \mathrm{~h}$ ) and tested with oxidase test and glucose fermentation test. Coliform bacteria were determined on VRB medium (Violet Red Bile, Difco $211695,37^{\circ} \mathrm{C} \pm 1{ }^{\circ} \mathrm{C}, 24 \pm 2 \mathrm{~h}$ ). Aerobic plate count was determined using Plate Count Agar, (Difco $247940,30^{\circ} \mathrm{C}, 72 \mathrm{~h}$ ). Lactic acid bacteria were determined on MRS medium (Lactobacilli MRS Broth, Difco 288130, Bacto Agar 15 $\mathrm{I} \mathrm{I}^{-1}$, Difco 214010, anaerobic incubation $30^{\circ} \mathrm{C}, 72 \mathrm{~h}$ ). Aerobic stability was measured as described by Seppälä et al. (2016) from silage (850 g) and TMR samples (990 g). The data collection lasted for 235 hours.

Statistical analyses were performed using SAS GLM procedure. The statistical model included the fixed effect of additive treatment (4 levels, 3 replicates). Analysis was conducted separately for both FBW and PW as well as for TMRs prepared from the silages. Differences between treatments (LS means) in fermentation quality and aerobic stability were compared using the Tukey test. In case of $\mathrm{TMR}_{\text {bob }}$ there was only 3 treatment levels with 3 replicates. Results of microbial counts were not statistically analysed because many of the counts were below the lower detection limit.
\end{abstract}

\title{
Results \\ Quality of the harvested crop prior to ensiling
}

The proportion of legumes in the mixtures was 84 and $89 \%$ for FBW and PW, respectively. Despite good weather, the immature crops were very wet, and the DM content was 173 and $181 \mathrm{~g} \mathrm{~kg}^{-1}$ for FBW and PW, respectively. Chemical composition of the harvested crops prior to ensiling is presented in Table 2. Numbers of enterobacteria, coliforms and lactic acid bacteria were all above one million $\mathrm{cfu}^{-1}$ prior to ensiling. Yeast and mould counts were both 280000-350000 $\mathrm{cfu} \mathrm{g}^{-1}$ prior to ensiling (Table 2).

Table 2. Chemical composition and microbial quality of the whole crops prior to ensiling and concentrate feed components used for total mixed ratios in aerobic stability tests

\begin{tabular}{|c|c|c|c|c|c|c|}
\hline & $\begin{array}{l}\text { Faba bean- } \\
\text { wheat }\end{array}$ & Pea-wheat & $\begin{array}{l}\text { Barley } \\
\text { grains }\end{array}$ & Oats grains & $\begin{array}{l}\text { Brewer's } \\
\text { grains }\end{array}$ & Straw \\
\hline Proportion of legume in the mixture on DM basis & 0.837 & 0.892 & & & & \\
\hline Dry matter (DM), $\mathrm{g} \mathrm{kg}^{-1}$ & 173 & 181 & 889 & 906 & 319 & 923 \\
\hline \multicolumn{7}{|l|}{ Composition, $\mathrm{g} \mathrm{kg}^{-1} \mathrm{DM}$} \\
\hline Ash & 63.1 & 70.1 & & & & \\
\hline Crude protein & 177 & 206 & & & & \\
\hline Water soluble carbohydrates (WSC) & 156 & 176 & & & & \\
\hline Starch & 93.9 & 76.1 & & & & \\
\hline Neutral detergent fibre & 476 & 392 & & & & \\
\hline D-value & 621 & 664 & & & & \\
\hline Buffering capacity, mekv kg-1 DM & 402 & 431 & & & & \\
\hline $\begin{array}{l}\text { Buffering capacity (BC), } \\
\text { lactic acid needed } \mathrm{g} \mathrm{kg}^{-1} \mathrm{DM}\end{array}$ & 68.8 & 95.1 & & & & \\
\hline Fermentation coefficient & 35.5 & 32.9 & & & & \\
\hline \multicolumn{7}{|l|}{ Microbial counts, $\log 10$ cfu g $^{-1}$} \\
\hline Enterobacteria & 6.58 & 6.91 & & & & \\
\hline Coliform bacteria & 6.59 & 6.80 & $<1$ & $<1$ & 1.85 & $>3.18$ \\
\hline Lactic acid bacteria & 6.97 & 6.02 & & & & \\
\hline Yeasts & 5.45 & 5.49 & 5.28 & 4.89 & 2.9 & 4.36 \\
\hline Moulds & 5.46 & 5.54 & 4.4 & 5.59 & 2.78 & 5.94 \\
\hline
\end{tabular}




\section{Quality and stability of the silages and TMRs}

Due to high moisture concentration, the silages were prone for extensive fermentation (Tables 3 and 4). LAB was unable to make significant differences into fermentation profile of FBW silages. Control and LAB treatments in FBW silages resulted in lactic acid 124-130, acetic acid 26-28 and ethanol 18-22 $\mathrm{g} \mathrm{kg}^{-1}$ DM, propionic acid and bytyric acid were both less than $1 \mathrm{~g} \mathrm{~kg}^{-1} \mathrm{DM}$, $\mathrm{pH}$ was 4.0-4.1 and WSC was 12-14 $\mathrm{g} \mathrm{kg}^{-1} \mathrm{DM}$. ACID treatment efficiently restricted fermentation of FBW silages resulting in lactic acid 17, acetic acid 8 and WSC $146 \mathrm{~g} \mathrm{~kg}^{-1} \mathrm{DM}$. Also proteolysis was inhibited by ACID treatment (ammonium- $\mathrm{N} 51$ compared to $69 \mathrm{~g} \mathrm{~kg}^{-1}$ total $\mathrm{N}$ in other treatments). Analyzed propionic acid in ACID treated silages was mainly derived from the additive. LAB2 was able to improve aerobic stability of FBW compared to control and ACID treatments.

Also PW silages went through extensive fermentation, accompanied with a substantial extent of proteolysis. All the PW silages had high ammonium-N concentration (average $89 \mathrm{~g} \mathrm{~kg}^{-1}$ total $\mathrm{N}$ ). Fermentation profiles of Control and LAB treatments were quite similar, lactic acid 133-140, acetic acid 22-27 and ethanol 32-35 g kg ${ }^{-1}$ DM, while propionic acid and bytyric acid were both less than $1 \mathrm{~g} \mathrm{~kg}^{-1} \mathrm{DM}, \mathrm{pH}$ was 4.1 and WSC was $10-17 \mathrm{~g} \mathrm{~kg}^{-1} \mathrm{DM}$. LAB2 slightly spared WSC (difference $6.6 \mathrm{~g} \mathrm{~kg}^{-1} \mathrm{DM}$ compared to control) by reducing the amount of acetic acid (difference $4.6 \mathrm{~g} \mathrm{~kg}^{-1} \mathrm{DM}$ compared to Control). ACID treatment had a greater effect on fermentation quality. Main fermentation products in PW-ACID were lactic acid and ethanol (81 and $69 \mathrm{~g} \mathrm{~kg}^{-1}$ DM respectively), while WSC was $21 \mathrm{~g} \mathrm{~kg}^{-1}$ DM. ACID treatment clearly improved aerobic stability ( $>235$ hours compared to less than 66 hours for other treatments), which was also reflected into the stability of TMR.

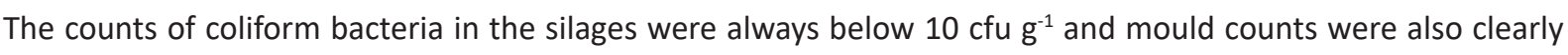
below the level detected in the crop prior to ensiling (mould count in FBW $<4$ and in PW $<3 \log _{10}$ cfu g ${ }^{-1}$ ). In PW silages only ACID treatment was able to drop the yeast count during ensiling, while in FBW silages all the treatments were quite equally effective against yeasts (Fig.1). The ACID treated PW silage had the longest aerobic stability. Microbiological quality of TMR ingredients is presented in Table 4.

Table 3. Fermentation quality ( $\left.\mathrm{g} \mathrm{kg}^{-1} \mathrm{DM}\right)$ and aerobic stability of the Faba bean - wheat (FBW) silages and TMR's

\begin{tabular}{|c|c|c|c|c|c|c|}
\hline & \multicolumn{4}{|c|}{ Faba bean - wheat (FBW) } & \multirow{2}{*}{ SEM } & \multirow{2}{*}{$\begin{array}{c}\text { Treatment } \\
p \text {-value }\end{array}$} \\
\hline & Control & LAB1 & LAB2 & ACID & & \\
\hline Dry matter (DM), $\mathrm{g} \mathrm{kg}^{-1}$ & 170 & 174 & 172 & 171 & 1.074 & 0.232 \\
\hline $\mathrm{pH}$ & $4.01^{B}$ & $4.05^{B}$ & $4.02^{B}$ & $4.24^{\mathrm{A}}$ & 0.012 & $<0.001$ \\
\hline Formic acid & & & & 18.3 & & \\
\hline Lactic acid & $130^{A}$ & $124^{\mathrm{AB}}$ & $130^{A}$ & $17.0^{\mathrm{B}}$ & 2.44 & $<0.001$ \\
\hline Acetic acid & $27.4^{\mathrm{A}}$ & $26.1^{\mathrm{A}}$ & $27.5^{\mathrm{A}}$ & $8.0^{c}$ & 0.61 & $<0.001$ \\
\hline Propionic acid & $0.80^{\mathrm{B}}$ & $0.82^{B}$ & $0.80^{\mathrm{B}}$ & $6.8^{\mathrm{A}}$ & 0.11 & $<0.001$ \\
\hline Butyric acid & $0.53^{B}$ & $0.60^{A B}$ & $0.55^{\mathrm{B}}$ & $0.63^{A}$ & 0.017 & 0.010 \\
\hline VFA & $28.8^{A}$ & $27.7^{A}$ & $29.0^{A}$ & $15.8^{c}$ & 0.60 & $<0.001$ \\
\hline WSC & $12.0^{\mathrm{B}}$ & $15.2^{B}$ & $14.1^{\mathrm{B}}$ & $146^{\mathrm{A}}$ & 5.06 & $<0.001$ \\
\hline Ethanol & $21.7^{A}$ & $20.6^{A}$ & $17.9^{\mathrm{A}}$ & $10.1^{\mathrm{B}}$ & 1.09 & $<0.001$ \\
\hline Amm. N, $\mathrm{g} \mathrm{kg}^{-1} \mathrm{~N}$ & $67.7^{\mathrm{B}}$ & $69.2^{\mathrm{B}}$ & $69.8^{B}$ & $50.7^{A}$ & 2.00 & $<0.001$ \\
\hline Sum of fermentation acids and ethanol & $181^{\mathrm{A}}$ & $172^{\mathrm{A}}$ & $177^{\mathrm{A}}$ & $43^{B}$ & & $<0.001$ \\
\hline \multicolumn{7}{|l|}{ Microbial counts, $\log _{10} \mathrm{cfu} \mathrm{g}^{-1}$} \\
\hline Coliform bacteria & $<10$ & $<10$ & $<10$ & $<10$ & & \\
\hline Yeasts (min - max) & $\leq 4$ & $\leq 4$ & $\leq 4$ & $3.95-4.93$ & & \\
\hline Moulds & $<4$ & $<4$ & $<4$ & $<3$ & & \\
\hline \multicolumn{7}{|l|}{ Aerobic stability, $\mathrm{h}$} \\
\hline Silages & $56.2^{B}$ & $88.3^{A B}$ & $101.2^{\mathrm{A}}$ & $59.4^{B}$ & 9.17 & 0.021 \\
\hline $\mathrm{TMR}_{\text {bobs }}$ & 49.7 & 56.9 & 62.9 & 49.7 & 3.73 & 0.099 \\
\hline
\end{tabular}

Treatments: Control = without additive; ACID = formic acid based additive, LAB1 = lactic acid bacteria strains, LAB2 = lactic acid bacteria strains and enzymes. SEM = Standard error of the means; VFA = sum of volatile fatty acids C2-C6; WSC = Water soluble carbohydrates; Amm. = Ammonium. Ammonium derived from ACID treatment $\left(10.5 \mathrm{~g} \mathrm{~kg}^{-1} \mathrm{~N}\right)$ subtracted from the analyzed ammonium content; $\mathrm{TMR}_{\mathrm{bobs}}=$ TMR total mixed ration including barley, oats and brewer's grain and straw. Differences within the same row without same superscript differ significantly from each other $(p<0.05$, Tukey test). 
Table 4. Fermentation quality ( $\left.\mathrm{kg}^{-1} \mathrm{DM}\right)$ and aerobic stability of the Pea - wheat (PW) silages and TMR's

\begin{tabular}{|c|c|c|c|c|c|c|}
\hline & \multicolumn{4}{|c|}{ Pea - wheat (PW) } & \multirow{2}{*}{ SEM } & \multirow{2}{*}{$\begin{array}{c}\text { Treatment } \\
p \text {-value }\end{array}$} \\
\hline & Control & LAB1 & LAB2 & ACID & & \\
\hline Dry matter (DM), $\mathrm{g} \mathrm{kg}^{-1}$ & 182 & 189 & 185 & 189 & 3.84 & 0.528 \\
\hline $\mathrm{pH}$ & $4.06^{\mathrm{B}}$ & $4.05^{\mathrm{B}}$ & $4.07^{\mathrm{B}}$ & $4.20^{\mathrm{A}}$ & 0.012 & $<0.001$ \\
\hline Formic acid & & & & 18.3 & & \\
\hline Lactic acid & $140^{\mathrm{A}}$ & $135^{\mathrm{A}}$ & $133^{\mathrm{A}}$ & $81.4^{\mathrm{B}}$ & 3.94 & $<0.001$ \\
\hline Acetic acid & $27.1^{\mathrm{A}}$ & $22.5^{\mathrm{B}}$ & $25.8^{\mathrm{A}}$ & $22.0^{\mathrm{B}}$ & 0.52 & $<0.001$ \\
\hline Propionic acid & $0.90^{\mathrm{B}}$ & $0.79^{\mathrm{B}}$ & $0.81^{\mathrm{B}}$ & $6.0^{\mathrm{A}}$ & 0.085 & $<0.001$ \\
\hline Butyric acid & $0.79^{A}$ & $0.51^{\mathrm{B}}$ & $0.54^{\mathrm{B}}$ & $0.58^{\mathrm{B}}$ & 0.044 & 0.010 \\
\hline VFA & $29.7^{\mathrm{A}}$ & $23.9^{\mathrm{B}}$ & $27.2^{\mathrm{A}}$ & $28.8^{\mathrm{A}}$ & 0.62 & $<0.001$ \\
\hline WSC & $10.3^{c}$ & $16.9^{\mathrm{B}}$ & $9.87^{c}$ & $21.2^{\mathrm{A}}$ & 0.637 & $<0.001$ \\
\hline Ethanol & $34.7^{\mathrm{B}}$ & $31.7^{\mathrm{B}}$ & $32.6^{\mathrm{B}}$ & $68.5^{\mathrm{A}}$ & 1.47 & $<0.001$ \\
\hline Amm. $\mathrm{N}, \mathrm{g} \mathrm{kg}^{-1} \mathrm{~N}$ & $92.4^{\mathrm{AB}}$ & $84.7^{\mathrm{B}}$ & $94.3^{\mathrm{A}}$ & $84.3^{\mathrm{B}}$ & 1.97 & 0.013 \\
\hline $\begin{array}{l}\text { Sum of fermentation acids } \\
\text { and ethanol }\end{array}$ & 204 & 191 & 193 & 179 & 5.49 & 0.063 \\
\hline \multicolumn{7}{|l|}{ Microbial counts, $\log _{10} \mathrm{cfu} \mathrm{g}^{-1}$} \\
\hline Coliform bacteria & $<10$ & $<10$ & $<10$ & $<10$ & & \\
\hline Yeasts (min - max) & $5.11-5.96$ & $5.34-5.85$ & $4.86-5.38$ & $<2-3.88$ & & \\
\hline Moulds & $<2$ & $<2$ & $<3$ & $<2$ & & \\
\hline \multicolumn{7}{|l|}{ Aerobic stability, $\mathrm{h}$} \\
\hline Silages & $56.8^{\mathrm{B}}$ & $56.8^{\mathrm{B}}$ & $65.4^{\mathrm{B}}$ & $>235.0^{A}$ & 7.31 & $<0.001$ \\
\hline $\mathrm{TMR}_{\text {bob }}$ & $52.9^{\mathrm{B}}$ & $48.9^{\mathrm{B}}$ & & $107.9^{A}$ & 2.55 & $<0.001$ \\
\hline $\mathrm{TMR}_{\text {bobs }}$ & $45.7^{\mathrm{B}}$ & $46.1^{\mathrm{B}}$ & $55.6^{\mathrm{B}}$ & $101.2^{\mathrm{A}}$ & 3.50 & $<0.001$ \\
\hline
\end{tabular}

Treatments: Control = without additive; $A C I D$ = formic acid based additive; $L A B 1$ = lactic acid bacteria strains; $L A B 2$ = lactic acid bacteria strains and enzymes. SEM = Standard error of the means; VFA = sum of volatile fatty acids C2 - C6; WSC = Water soluble carbohydrates; Amm. = Ammonium. Ammonium derived from ACID treatment $\left(8.6 \mathrm{~g} \mathrm{~kg}^{-1} \mathrm{~N}\right)$ subtracted from the analyzed ammonium content; $\mathrm{TMR}_{\text {bob }}=$ total mixed ration including barley, oats and brewer's grain, $\mathrm{TMR}_{\text {bobs }}=\mathrm{TMR}$ including barley, oats and brewer's grain and straw. Differences within the same row without same superscript differ significantly from each other $(p<0.05$, Tukey test).

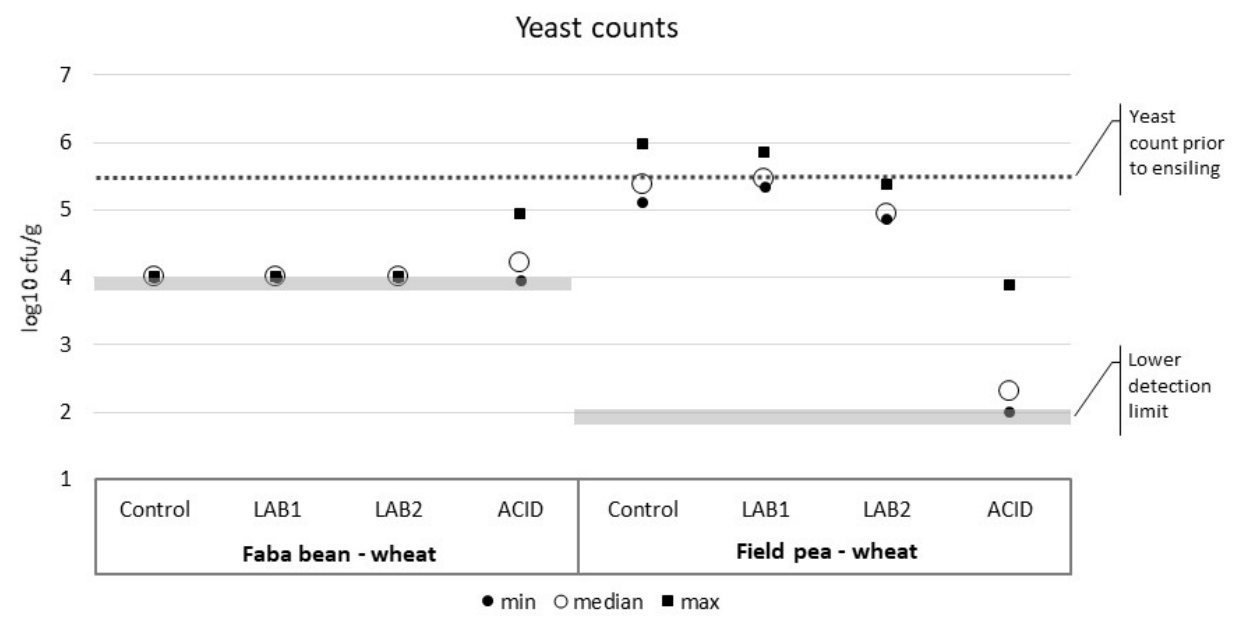

Fig. 1. Yeast counts of the whole crop silages. Different lower detection limit was used for different silage types. Control = without additive; $L A B 1=$ lactic acid bacteria strains; $L A B 2$ = lactic acid bacteria strains and enzymes; $\mathrm{ACID}=$ formic acid based additive. For additive treatments, see Table 1. 


\section{Discussion}

\section{FBW and PW as silage raw materials}

Ensilability refers to how challenging the forage crop is to ensile and it can be evaluated by calculating the so-called fermentation coefficient based on DM and WSC concentrations and buffering capacity of the crop (Weissbach and Honig 1996). The values (less than 36) for the current crops suggest that they were difficult or intermediate in ensilability (Weissbach and Honig 1996).

In this trial the ensiled crops had very high moisture content despite good weather conditions during harvesting. Pursiainen and Tuori (2008) also experienced that especially the monocultured faba bean whole crop was wet (DM $155 \mathrm{~g} \mathrm{~kg}^{-1}$ ) and all grain legume crops had lower DM concentration than wheat whole crop. When ensiling wet material, the effluent losses can be remarkable. Some forecasting equations suggest that effluent loss from plant material having DM concentration of 170-180 g kg-1 could be $120-290 \mathrm{~g} \mathrm{~kg}^{-1}$ (Jones and Jones 1995). In laboratory scale trial the effluent is typically not pressed out as efficiently. In this trial the average weight loss during ensiling was $44 \mathrm{~g} \mathrm{~kg}^{-1}$, which partly was effluent lost unintended. Prewilting can be an effective method to reduce effluent losses, but risks related to prewiling (shredding grains, soil contamination, unexpected rain) need to be managed (Rondahl et al. 2006). Much higher DM concentration (389 $\mathrm{g} \mathrm{kg}^{-1}$ ) of FBW silage was achieved in the trial conducted in Southern Finland (Lamminen et al. 2015) due to different weather conditions and applying a harvesting method which enabled prewilting.

The WSC concentration of the FBW and PW crops were $50-70 \%$ higher compared to grass typically harvested for silage in Finland, as measured average WSC concentration in first and second cut of timothy-meadow fescue swards were 112 and $99 \mathrm{~g} \mathrm{~kg}^{-1} \mathrm{DM}$ (Huhtanen et al. 2005). Further, the buffering capacity was quite similar to that in timothy-meadow fescue crop measured by Seppälä et al. (2016; 340-483 mekv kg-1 DM). Based on measured WSC and buffering capacity, the FBW and PW silages should not be more difficult to ensile than typical timothymeadow fescue if efficient prewilting is used. However, Pursiainen and Tuori (2008) measured clearly higher buffering capacity from pure stand faba bean $\left(588 \mathrm{mEq} \mathrm{kg}^{-1} \mathrm{DM}\right)$ and pea (710 $\left.\mathrm{mEq} \mathrm{kg}^{-1} \mathrm{DM}\right)$ suggesting high variability in this parameter between years or stands.

All the measured microbial numbers in the crop samples were on high level. The count of natural LAB in forage was above 1 million cfu $\mathrm{g}^{-1}$, which has been set as the threshold for successful ensiling (Weissbach and Honig 1996). Regarding high WSC, low DM concentration and high LAB count, the preconditions for extensive fermentation were present.

In vitro digestibility of legume whole crops was relatively low despite leafy green crop which did not show any leaf loss due to plant diseases or drought. The in vitro pepsin-cellulase method has been shown to be a useful method for determining digestibility of grain legume whole crops (Kuoppala et al. 2014b). Despite relatively low digestibility, inclusion of whole crop silages into ruminant diets may be beneficial due to increased DM intake of the whole diet (Huhtanen et al. 2007). Nevertheless, Huuskonen et al. (2016) observed that replacing timothy silage by FBW or by PW silage did not have any remarkable effect on animal performance, carcass characteristics or meat quality of the growing bulls but higher crude protein concentration of whole crop legume silages impaired nitrogen utilization compared to timothy silage based diet.

\section{Fermentation quality of control and LAB silages}

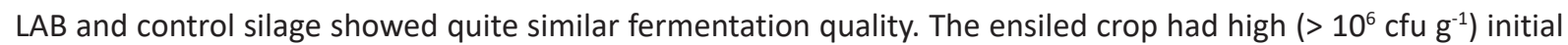
number of lactic acid bacteria, and changes in fermentation quality contributed by the use of LAB were so small that their practical value is minimal as such (Tables 3 and 4). However, improvement of aerobic stability caused by LAB2 in FBW may have practical value.

Natural LAB present in the crop produced high amounts of lactic acid (130 or $140 \mathrm{~g} \mathrm{~kg}^{-1} \mathrm{DM}$ in FBW and PW respectively), while acetic acid ( $27 \mathrm{~g} \mathrm{~kg}^{-1} \mathrm{DM}$ ) contributed 95 and $91 \%$ of the total VFA in FBW and PW respectively, when ensiled without additive. The amount of butyric acid was below $1.0 \mathrm{~g} \mathrm{~kg}^{-1} \mathrm{DM}$ in all the silages. According to DLG (Kaiser et al. 2006), the fermentation quality of control silage was very good. It is notable that the DLG system only takes into account the $\mathrm{pH}$ and the VFA concentration of the silages. According to the silage quality criteria used in Finland for several decades (Artturi registered trade mark for the service, Valio Ltd., Finland), both lactic acid concentration and VFA concentration were above the threshold for good quality silage (80 and $20 \mathrm{~g} \mathrm{~kg}^{-1} \mathrm{DM}_{\text {, }}$ respectively, Moisio and Heikonen 1992). 
High amount of acids (sum of lactic acid and VFA) in control silage would reduce silage DM intake (Huhtanen et al. 2002, 2007) the reduction being higher in high levels of fermentation acids. Huhtanen et al. (2002) estimat-

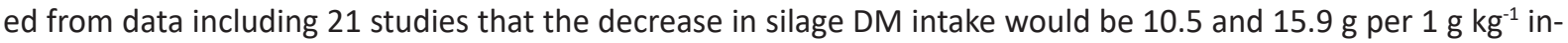
crease in total fermentation acid concentration at concentrations of 70 and $120 \mathrm{~g} \mathrm{~kg}^{-1} \mathrm{DM}$, respectively. In the revised model for calculating silage DM intake index the decrease was $12.8 \mathrm{~g}$ per $1 \mathrm{~g}$ fermentation acids $\mathrm{kg}^{-1} \mathrm{DM}$ (Huhtanen et al. 2007).

The WSC concentration below $20 \mathrm{~g} \mathrm{~kg}^{-1}$ DM has been regarded as a sign of poor quality in Artturi (Valio Ltd, Finland) silage quality evaluation. Reasoning for that is that low WSC content may pose a risk to silage quality during an extended ensiling period (Moisio and Heikonen 1992) predisposing to secondary fermentation and production of butyric acid (McDonald et al. 1991). However, in control silage pH was clearly below 4.2 which is regarded as the threshold for inhibiting growth of clostridia which typically are responsible for production of butyric acid (McDonald et al. 1991). Risk for butyric acid fermentation is high with this kind of wet plant material, especially if the forage has low concentration of nitrate that could prevent the growth of clostridia (McDonald et al. 1991, Pursiainen and Tuori 2008). Borreani et al. (2009) measured $72 \mathrm{~g} \mathrm{~kg}^{-1}$ DM butyric acid in faba bean whole crop silage.

In both plant materials, the natural LAB were able to prevent extensive proteolysis during ensiling as ammonium$\mathrm{N}$ concentration was in both cases below $100 \mathrm{~g} \mathrm{~kg}^{-1}$ total $\mathrm{N}$. The PW silages had clearly higher ammonium- $\mathrm{N}$ concentration than the FBW silages. Ammonium-N concentration is a key parameter to reflect silage quality. According to Wilkinson (1990), silage with ammonium- $\mathrm{N}$ in a range of $50-100 \mathrm{~g} \mathrm{~kg}^{-1}$ total $\mathrm{N}$ is regarded well fermented, while silage having ammonium- $\mathrm{N}$ below $50 \mathrm{~g} \mathrm{~kg}^{-1}$ total $\mathrm{N}$ is very well fermented. Increase in silage ammonium- $\mathrm{N}$ concentration in silage has been linked to reduced intake of silage DM (Huhtanen et al. 2002).

\section{Fermentation quality of ACID silages}

The ACID treatment was able to restrict fermentation especially in FBW silages where the sum of fermentation acids was $138 \mathrm{~g} \mathrm{~kg}^{-1} \mathrm{DM}$ lower in ACID treated silages compared to control silages. This is equal to an increase of silage DM intake by $1.61 \mathrm{~kg}$ DM by dairy cows based on the silage DM intake index (Huhtanen et al. 2007). In PW silages, the effect of restriction of fermentation by ACID treatment would be equal to increase of $0.77 \mathrm{~kg}$ daily silage DM intake by dairy cows (Huhtanen et al. 2007). It is notable, that ACID treatment is equal to only 3.7 I t-1 of $80 \%$ formic acid, while traditional application recommendation has been $6 \mathrm{It}^{-1}$ (as $80 \%$ formic acid) on pure leguminous plant materials.

The ACID treated FBW silage was of good quality according to majority of fermentation quality parameters. The PW seemed to be more challenging to ensile, because not even the ACID treatment was able to result in good quality silage according to Artturi ${ }^{\bullet}$ criteria (too high $\mathrm{pH}$, VFA and ammonium-N concentration and too low WSC concentration). Ethanol contributed $38 \%$ of the fermentation products of ACID treated PW silages. Production of ethanol during fermentation increases DM but not energy losses compared to lactic acid fermentation (Rooke and Hatfield 2003). Ethanol does not decrease silage intake (Huhtanen et al. 2002) and has high energy value for animals. Silage ethanol concentration does not have effect on energy corrected milk yield, milk fat or protein yield, but increases milk fat concentration (Huhtanen et al. 2003). The high ethanol content of PW silages treated with ACID suggests strong role of yeasts during fermentation although they were not alive at the time of silo opening as demonstrated by both the good aerobic stability and low yeast numbers (maximum $7500 \mathrm{cfu} \mathrm{g}^{-1}$ ) of those silages. Rinne et al. (2016) detected that combination of formic acid and propionic acid was able to restrict formation of ethanol compared to additives containing only formic acid and salts of formic acid. The ACID treatment was able to reduce ethanol production in FBW silages but increased ethanol production in PW silages. Reason for that is unknown.

\section{Aerobic stability of the silages and TMRs}

After silo opening, the aerobic microbes can grow utilizing the sugars and fermentation products of the silage (Wilkinson and Davies 2013). Respiration releases moisture and heat into the silage. Heating of high DM silage is a more commonly mentioned risk among farmers than heating of low DM silages. Reasons for that are higher porosity, difficulty to compact sufficiently and higher final temperature of high DM silage compared to low DM silage (Wilkinson and Davies 2013). However, certain temperature increase of low DM silage consumes remarkable more energy than the same temperature increase of drier feed due to high thermal capacity of water. Thus, even a small temperature increase of wet silage after silo opening may mean high energy losses and should therefore be regarded as a serious sign. 
Despite low DM concentration of the silages in this trial, only PW silage treated with ACID showed aerobic stability longer than one week which has been suggested as a practical target for silage stability (Wilkinson and Davies 2013). Formic acid may enhance yeast growth during early phases of ensiling but reduce their survival later during ensiling (Driehuis and van Wikselaar 1996), which may explain both high ethanol concentration and good stability of ACID treated PW silages. In this trial the FBW silages had yeast counts below $10^{5} \mathrm{cfu} \mathrm{g}^{-1}$ suggesting low risk for heating (Wilkinson and Davies 2013), however those silages had poor stability. Potentially high moisture concentration may have promoted yeast growth. In the trial of Seppälä et al. (2016), low DM silage (DM $218 \mathrm{~g} \mathrm{~kg}^{-1}$ ) showed more than one week aerobic stability only if the yeast count was below $10^{2} \mathrm{cfu} \mathrm{g}^{-1}$.

Both crop types ensiled without additive started to heat almost immediately after silo opening and reached the heating of $2{ }^{\circ} \mathrm{C}$ above ambient temperature in 56-57 hours. The ACID treatment could improve the aerobic stability of PW silages while LAB2 improved the aerobic stability of FBW silage. It is difficult to explain why LAB2 was able to improve aerobic stability of FBW silage, because measured parameters compared to control silage do not give any explanation for that difference. Typically additives including only homolactic acid bacteria strains are not able to improve aerobic stability (Wilkinson and Davies 2013). High lactic acid and low acetic acid contents in silage treated with homofermentative LAB is susceptible to activity of lactate assimilating yeast, resulting in a decrease in lactic acid, $\mathrm{pH}$ rise and creating a favourable environment for spoilage microorganisms to generate heat in the silage. Acetic acid produced by heterofermentative LAB has often improved aerobic stability of silage (Driehuis et al. 1999). In this case, there was however no increase in acetic acid concentration in LAB2 silages.

Mixing TMR from the experimental silages reduced stability of the feed compared to the silage as such, which is line with observations of Seppälä et al. (2016) with moist grass silage. The reasons for the decreased stability of TMR compared to silage only include increased number of aerobic spoiling organisms via concentrate components as well as better oxygen availability after mixing the feed ingredients. In this trial the yeast and mould counts in the straw were in the same level as in grain. This may be the explanation for insignificant difference in TMR stability between the TMRs with or without straw. The brewer's grains had low yeast and mould counts (less than 3 $\log _{10} \mathrm{cfu} \mathrm{g}^{-1}$ ) compared to some earlier results (yeasts $>6.6$, moulds $>4.2 \log _{10} \mathrm{cfu} \mathrm{g}^{-1}$, Seppälä et al. 2013, 2016) suggesting smaller role of brewer's grains in the TMR heating in this trial.

In the current trial the most stable silage resulted in a TMR with the longest stability, as suggested also by Kung (2005). However, the correlation between the stability of silage and TMR is not always consistent, as shown by Seppälä et al. (2016) who found that stable control silage (without additive) gave poor stability to TMR. In this trial, LAB2 could improve stability of FBW silage, but no differences were seen in stability of TMR prepared from FBW silages.

\section{Conclusions}

Wet FBW and PW silages went through extensive fermentation dominated by lactic acid production. Natural LAB population was strong in both crops so the LAB treatments were not able to make remarkable changes in the fermentation profile of the silages. Ammonium-N in FBW silages was less than 70 and $84-94 \mathrm{~g} \mathrm{~kg}^{-1}$ total N in PW silages. The ACID treatment restricted fermentation and prevented proteolysis of FBW silage but turned the fermentation of PW silage towards ethanol production. Poor aerobic stability was a general problem, expect that improvements were achieved by LAB2 in FBW silage and by ACID treatment in PW silage. Results of this trial show that the potential agronomic benefits of cultivating grain legume-cereal mixtures may be counterbalanced by the difficulty of ensiling. It is notable, that prewilting may not be possible or might cause too high shredding losses.

\section{Acknowledgements}

This study was partially funded by the Centre for Economic Development, Transport and the Environment for Northern Ostrobothnia. We wish to thank Katja Kuusisto (University of Helsinki, Finland) who contributed to this work as a M.Sc. student.

\section{References}

Borreani, G., Chion, A.R., Colombini, S., Odoardi, M., Paoletti, R. \& Tabacco, E. 2009. Fermentative profiles of field pea (Pisum sativum), faba bean (Vicia faba) and white lupin (Lupinus albus) silages as affected by wilting and inoculation. Animal Feed Science and Technology 151: 316-323. https://doi.org/10.1016/j.anifeedsci.2009.01.020 
Driehuis, F. \& van Wikselaar, P.G. 1996. Effects of addition of formic, acetic or propionic acid to maize silage and low dry matter grass silage on the microbial flora and aerobic stability. In: Jones, D.I.H., Jones, R., Dewhurst, R., Merry, R. \& Haigh, P.M. (eds.). Proceedings of the 11th International Silage Conference, Aberystwyth, UK. 8-11 September 1996. IGER, Aberystwyth, UK. p. $256-257$.

Driehuis, F., Oude Elferink, S.J.W.H. \& Spoelstra, S.F. 1999. Anaerobic lactic acid degradation during ensilage of whole crop maize inoculated with Lactobacillus buchneri inhibits yeast growth and improves aerobic stability. Journal of Applied Microbiology 87: 583-594. https://doi.org/10.1046/j.1365-2672.1999.00856.x

Huhtanen, P., Khalili, H., Nousiainen, J.I., Rinne, M., Jaakkola, S., Heikkilä, T. \& Nousiainen, J. 2002. Prediction of the relative intake potential of grass silage by dairy cows. Livestock Production Science 73: 111-130. https://doi.org/10.1016/S0301-6226(01)00279-2

Huhtanen, P., Nousiainen, J.I., Khalili, H., Jaakkola, S. \& Heikkilä, T. 2003. Relationships between silage fermentation characteristics and milk production parameters: analyses of literature data. Livestock Production Science 81: 57-73. https://doi.org/10.1016/ S0301-6226(02)00195-1

Huhtanen, P., Nousiainen, J. \& Rinne, M. 2005. Prediction of silage composition and organic matter digestibility from herbage composition and pepsin-cellulase solubility. Agricultural and Food Science 14: 154-165. https://doi.org/10.2137/145960605774826046

Huhtanen P., Nousiainen, J. \& Rinne, M. 2006. Recent developments in forage evaluation with special reference to practical applications. Agricultural and Food Science 15: 293-323. https://doi.org/10.2137/145960606779216317

Huhtanen P., Rinne, M. \& Nousiainen, J. 2007. Evaluation of the factors affecting silage intake of dairy cows: a revision of the relative silage dry-matter intake index. Animal 1: 758-770. https://doi.org/10.1017/S175173110773673X

Huuskonen, A., Pesonen, M. \& Honkavaara, M. 2016. Performance and meat quality of Nordic Red and Aberdeen Angus bulls offered faba bean or field pea based whole crop legume-cereal silages. Agricultural and Food Science 25: 1-12. https://doi. org/10.23986/afsci.52311

Jones, D.I.H. \& Jones, R. 1995. The Effect of Crop Characteristics and Ensiling Methodology on Grass Silage Effluent Production. Journal of Agricultural Engineering Research 60: 73-81. https://doi.org/10.1006/jaer.1995.1001

Kaiser, E., Weiss, K., Nußbaum, H.-J., Kalzendorf, K., Pahlow, G., Schenkel, H., Schwarz, F.J., Spiekers, H., Staudacher, W. \& Thaysen, J. 2006. Grobfutterbewertung. Teil B. DLG-Schlüssel zur Beurteilung der Gärqualität von Grünfuttersilagen auf Basis der chemischen Untersuchung. DLG_Information 2/2006. http://www.dlg.org/fileadmin/downloads/fachinfos/futtermittel/grobfutterbewertung_B. pdf. Accessed 22 August 2019.

Kung, L. Jr. 2005. Aerobic Stability of Silages. Proceedings of the Conference on Silage for Dairy Farms. Harrisburg, PA. http://www. academia.edu/6566050/Aerobic_Stability_of_Silages. Accessed 22 August 2019.

Kung, L. Jr. 2009. Potential factors that may limit the effectiveness of silage additives. In: Broderick, G.A. (ed.). Proceedings of the 15th International Silage Conference, Madison, Wisconsin, 2009. p. 37-45.

Kung, L. Jr. \& Muck, R.R. 1997. Animal response to silage additives. Proceedings of the Silage: field to feed bunk. NRAES-99. North American conference, Hershey, Pennsylvania February 11-13, 1997. Northeast Regional Agricultural Engineering Service, Cooperative Extension, Ithaca, New York, USA. p. 200-210.

Kung, L., Stokes, M.R. \& Lin, C.J. 2003. Silage Additives. In: Buxton, D.R., Muck, R.E. \& Harrison, J.H. (eds.). Silage Science and Technology. Agronomy Publication No 42. American Society of Agronomy, Madison, Wisconsin USA. p. 305-360.

Kuoppala, K., Huuskonen, A., Saarinen, E. \& Rinne, M. 2014a. Dry matter yields and feed values of faba bean and pea as bi-crops with wheat or oats in Northern Finland. In: Udén, P. (ed.). Proceedings of the 5th Nordic feed science conference, Uppsala, Sweden, 10-11 June, 2014. p. 169-173.

Kuoppala, K., Rinne, M., Lötjönen, T. \& Huuskonen, A. 2014b. Palkokasveja sisältävien kokoviljasäilörehujen rehuarvon tarkentaminen ruokinnan optimoimiseksi. In: Huuskonen, A. (ed.). Edistystä luomutuotantoon: loppuraportti. MTT Raportti 175: 35-51. http://urn.fi/URN:ISBN:978-952-487-587-5

Lamminen, M.E., Kokkonen, T.J., Halmemies-Beauchet-Filleau, A.I.K., Termonen, T.J., Vanhatalo, A.O. \& Jaakkola, S.L. 2015. Partial replacement of grass silage with faba bean whole-crop silage in the diet of dairy cows. In: van den Pol-van Dasselaar, A., Aarts, H.F.M., De Vliegher, A., Elgersma, A., Reheul, D., Reijneveld, J.A., Verloop, J. \& Hopkins, A. (eds.). Grassland and forages in high output dairy farming systems: Proceedings of the 18th Symposium of the European Grassland Federation. Wageningen Academic Publishers. p. 446-448.

McDonald, P., Henderson, A.R. \& Heron, S.J.E. 1991. The biochemistry of silage. 2nd edition, Marlow, UK. Chalcombe Publications. ISBN 0-948617-22-5. $340 \mathrm{p}$.

Moisio, T. \& Heikonen, M. 1992. AlV-rehun perusteet. Tampere, Finland. 170 p. (in Finnish).

Muck, R.E. \& O'Kiely, P. 1992. Aerobic deterioration of lucerne (Medicago sativa) and maize (Zea mays) silages-effects of fermentation products. Journal of the Science of Food and Agriculture 59: 145. ISBN 0-948617-22-5.149. https://doi.org/10.1002/ jsfa.2740590203

Phelan, P., Moloney, A.P., McGeough, E.J., Humphreys, J., Bertilsson, J., O’Riordan, E.G. \& O’Kiely, P. 2015. Forage legumes for grazing and conserving in ruminant production systems. Critical Reviews in Plant Sciences 34: 281. ISBN 0-948617-22-5.326. https:// doi.org/10.1080/07352689.2014.898455

Playne, M.J. \& McDonald, P. 1966. The buffering constituents of herbage and of silage. Journal of the Science of Food and Agriculture 17: 264-268. https://doi.org/10.1002/jsfa.2740170609

Pursiainen, P. \& Tuori, M. 2008. Effect of ensiling field bean, field pea and common vetch in different proportions with wholecrop wheat using formic acid or an inoculant on fermentation characteristics. Grass and Forage Science 63: 60-78. https://doi. org/10.1111/j.1365-2494.2007.00614.x

Rinne, M., Kuoppala, K., Mäki, M., Seppälä, A. \& Jalava, T. 2016. Effects of seven formic acid based additives on grass silage fermentation and aerobic stability. In: Rajčáková, L. (ed.). Proceedings of 17th International Conference Forage Conservation 27th - 29th September, 2016 Hotel Bellevue - Horný Smokovec, Slovak Republic National Agricultural and Food Centre Slovak, University of Agriculture Nitra, NutriVet, Ltd. Pohořelice. p.115-116. 
Rondahl, T., Bertilsson, J., Lindgren, E. \& Martinsson, K. 2006. Effects of stage of maturity and conservation strategy on fermentation, feed intake and digestibility of whole-crop pea-oat silage used in dairy production. Acta Agriculturae Scandinavia, Section A, Animal Science 56: 137-147. https://doi.org/10.1080/09064700701284936

Rooke, J.A. \& Hatfield, R.D. 2003. Biochemistry of Ensiling. In: Buxton, D.R., Muck, R.E. \& Harrison, J.H. (eds.). Silage Science and Technology. Agronomy Publication No 42, American Society of Agronomy, Madison, Wisconsin USA. p. 95-140.

Seppälä, A., Heikkilä T., Mäki, M., Miettinen, H. \& Rinne, M. 2013. Controlling aerobic stability of grass silage-based total mixed rations. Animal Feed Science and Technology 179: 54-60. https://doi.org/10.1016/j.anifeedsci.2012.11.011

Seppälä, A., Heikkilä, T., Mäki, M. \& Rinne, M. 2016. Effects of additives on the fermentation and aerobic stability of grass silages and total mixed rations. Grass and Forage Science 71: 458-471. https://doi.org/10.1111/gfs.12221

Seppälä, A. \& Nyholm, L. 2019. Silage quality in Finland. In: Jambor, V. \& Malá, S. (eds.) Proceedings 18th International Symposium of Forage Conservation, Brno, Czech Republic, August 13-16, 2019. Mendelova univerzita v. Brně. p.100-101.

Strauss, G. \& Hayler, R. 2001. Effects of organic acids on microorganisms. Kraftfutter 4: 1-4

Weissbach, F. \& Honig, H. 1996. Über die Vorhersage und Steuerung des Gärungsverlaufs bei der Silierung von Grünfutter aus extensivem Anbau. Landbauforschung Völkenrode 46: 10-17. (in German).

Weissbach, F., Schmidt, L. \& Hein, E. 1974. Method of anticipation of the run of fermentation in silage making based on the chmical composition of green fodder. Proceedings of the 12th International Grassland Congress, Moscow, Russia. Vol.3, Part 2. p. 663-673.

Wilkinson, J.M. 1990. Silage UK, Sixth Edition. Marlow, UK, Chalcombe Publications. 185 p.

Wilkinson, J.M. \& Davies, D.R. 2013. The aerobic stability of silage: key findings and recent developments. Grass and Forage Science 68: 1-19. https://doi.org/10.1111/j.1365-2494.2012.00891.x

Virtanen, A.I. 1944. AIV-järjestelmä karjanruokinnan perustana. Pellervo-seura, Helsinki, Finland. 298 p. (in Finnish). 